\title{
A Brief History of Prohibition and Treatment Solutions for Substance Abusers
}

\author{
David F. Duncan ${ }^{1, *}$, Thomas Nicholson ${ }^{2}$, John B. White ${ }^{2}$ and Gregory Ellis-Griffith ${ }^{2}$ \\ ${ }^{1}$ Brown University, Providence, RI 02912, USA \\ ${ }^{2}$ Western Kentucky University, 1906 College Heights BIvd. Bowling Green, KY 42101, USA
}

\begin{abstract}
The predominant policy of prohibition (i.e. "War on Drugs") emerged in the early Twentieth Century. It has been expanded on since that time to become the primary thrust of drug policy in almost every nation today. We will examine how this came about and the ways in which it has contributed to the maltreatment of substance abuse disorders.
\end{abstract}

Keywords: Prohibition, social history, criminalization, addiction.

This paper will explore the impact current drug policy has on the treatment of substance abuse disorders. The predominant policy of prohibition (i.e. "War on Drugs") emerged in the early Twentieth Century. It has been expanded on since then to become the primary thrust of drug policy in almost every nation today. We will examine how this came about and the ways in which it has contributed to the maltreatment of substance abuse disorders.

The premise of this paper is that national drug policy has had a direct and negative impact on the development and application of treatment modalities for substance abusers. Few categories of disease are so intertwined with the criminal justice system as the substance abuse disorders have become under prohibition. This has resulted in a limited number and range of treatment resources for these disorders. We believe that this situation would not be tolerated in such diseases as cancer or heart disease and are shocked and dismayed that it is promoted here.

Prohibition and criminalization of some drugs has not only complicated the treatment of abuse of those drugs but has affected the willingness of drug abusers to seek treatment. To many Americans obviously some drugs should be illegal. Few Americans are old enough to remember a time when all of the currently illegal drugs were legal or not yet discovered. Yet roughly a century ago, no drug was illegal in the United States. The history of how and why we came to outlaw certain drugs and not others is critical to our understanding the impact of drug policy on substance abuse treatment.

*Address correspondence to this author at 2039 Russellville Road, \#31, Bowling Green, KY 42101, USA; Tel: 270-796-6713;

E-mail: dfduncan@twc.com
While there had been religious prohibitions on the use of certain drugs, particularly alcohol in Islam and other faiths, secular prohibition enforced by the criminal law is a much more recent phenomenon. The first drug to be widely outlawed in such a manner was nicotine after it was introduced into Europe and Asia from North America (Duncan \& Gold, 1982).

Ahmed I, Sultan of the Ottoman Empire and Caliph of Islam from 1603 till 1617, outlawed the use of tobacco anywhere in the Islamic world and enforced strict penalties for violations. Attempts to enforce the prohibition seem to have been dropped during the unrest following his death, but were vigorously reinstated by Murad IV, who reigned from 1623 through1640. Murad not only renewed the prohibition but declared the penalty for violations to be death. Both Murad and his successor Ibrahim I (1640-1648) are reported to have often wandered the streets of Constantinople in disguise searching for smokers whom they would execute on the spot. Despite these acts tobacco use continued to grow. In the words of Corti (1931), "Even the fear of death was of no avail with the passionate devotees of the habit." When Mohammed IV, a habitual smoker, succeeded Ibrahim as Sultan, he promptly rescinded the laws against smoking and the practice became an accepted part of Turkish culture.

Similar failing battles against tobacco were fought in Japan and China. Tobacco use had been introduced into both nations by Portuguese seamen in the Sixteenth Century. In Japan penalties were repeatedly increased between 1603 and 1616 . Eventually not only the smoker but his wife, children, and parents were subject to execution. Nevertheless, the popularity of smoking continued to grow unabated and enforcement of the laws dwindled. By 1650, smoking tobacco had 
become a part of the tea ceremony performed with honored guests. In 1651, the anti-tobacco laws were repealed and tobacco was fully re-legalized.

Tobacco was more readily accepted in China, where it became a standard remedy for colds, malaria, and cholera. In 1638, the Chongzhen Emperor, concerned about the spread of Western influence and practices, issued an edict prohibiting tobacco use under penalty of decapitation. The edict, however, was soon withdrawn under pressure from the military, which was largely made up of Manchus most of whom were smokers. Three years later the prohibition was reinstated but it failed as surely as every other attempt around the world to outlaw tobacco. When the Ming Dynasty fell in 1644, the Qing Dynasty established by the Manchu conquerors ended all efforts to oppose tobacco use.

In 1634, Czar Michael of Russia issued an edict forbidding all use of tobacco. First offenders were publicly flogged and had their noses slit, while repeat offenders were exiled to Siberia for life. When this proved insufficient to suppress the habit, Michael's successor, Czar Alexis increased the penalty. Alexis ordered that smokers were to be publicly tortured, yet tobacco use continued to grow. By 1655, smoking tobacco or using snuff had become death penalty offenses. Nevertheless, tobacco use became common and after Czar Peter the Great took up the habit, he relegalized tobacco use in 1697 acknowledging "its wide use and ubiquitous secret trade" (Corti, 1931: 176-177; Brooks, 1952: 151).

Four lessons might be learned from this brief summary of some of mankind's earliest attempts at outlawing a drug: First, all drugs were once legal. Second, the drugs that are currently prohibited are not the necessary or obvious targets of such a policy. Third, as prohibition was not at all successful in suppressing use of tobacco, it seems to have been equally unsuccessful with the other drugs with which it has been tried. Fourth, more severe penalties, including the death penalty, do not seem to make prohibition any more successful (Duncan \& Gold, 1982).

The historical background of today's "War on Drugs" has additional roots in Asia. During the Nineteenth Century, many Chinese laborers were recruited to the United States to help build the transcontinental railroad. These laborers fulfilled the same need in the West that laborers recruited from Ireland did in the East and once the railroad was built were even more unwelcome as permanent residents than the Irish in the eyes of most Americans (Hoffmann, 1990). One result was the Chinese Exclusion Act of 1882 (Timmer \& Williamson, 1996). Another was a series of local ordinances in California cities beginning with an 1875 San Francisco ordinance that outlawed the smoking of opium (Helmer \& Vietorisz, 1974; Helmer, 1975; Hoffmann, 1990; Morgan, 1978).

"Although the anti-opium laws were largely an ideological tool to serve economic interests, their passage was supported by portraying opium smoking as an activity that put whites, and white females in particular, in morally precarious situations" (Holcomb, Williams, \& Demuth, 2004, p. 885). Evil Chinamen were depicted as luring White women to their "ruin" in opium dens and using their addiction to enslave them into a life of prostitution -- hence the growth of the popular term "White slavery" (Frost, 2005, 68-88). Morgan (1978: 58) cites a government report from the period that stated that, "The department of the police, in enforcing the law with regard to this matter, have found white women and Chinamen side by side under the effects of the drug -- a humiliating sight to anyone who has anything left of manhood." The real purpose of these ordinances is generally acknowledged by historians to have been to suppress the Chinese labor force (Holcomb, Williams, \& Demuth, 2004; Helmer, 1975; Helmer \& Vietorisz, 1974).

This earliest instance of American drug prohibition was moved to the level of a federal concern after the Spanish-American War (Lowes, 1966). One result of that war was that in 1896 the United States gained its first overseas territories - Puerto Rico and the Philippine Islands. Much of the laboring population of the Philippines, like that in China, was in the habit of smoking opium, including a substantial number who were addicted to opium. The Spanish colonial government had dealt with this by turning a blind eye to the occasional opium binges of non-addicts and by operating a government monopoly that provided opium to addicts.

With the US assuming the role of colonial power in the Philippines, the policies of the Spanish toward opium use were opened to question. Governor Taft appointed a War Department Commission of Inquiry (often called the Philippine Opium Commission) chaired by Charles Henry Brent, the Episcopal Bishop of the Philippines, to examine opium policy. The commission found the dispensing of opium to addicts 
distasteful and recommending the closure of the opium program. The commission also recommended that opium control should be addressed as a regional problem rather than on a nation by nation basis.

Bishop Brent was to become a leading figure in shaping the beginnings of America's prohibitionist policy toward drugs. The Bishop wrote to his friend President Theodore Roosevelt urging him to call for a regional conference to address the problem of opium addiction in Asia (Bewley-Taylor, 1999). As a result, the International Opium Commission, composed of representatives of all the colonial nations with territories in Asia, met in 1909 in Shanghai, China. The US was represented by Dr. Hamilton Wright, Dr. Charles C. Tenney, and Bishop Brent. The conference ended in a non-binding agreement to collaborate in the suppression of the opium trade.

In preparation for the Shanghai Conference, Secretary of State Elihu Root asked Congress to ban the importation of opium into the US. The result was the Smoking Opium Exclusion Act of 1909, which banned the importation of a weaker form of opium that was suitable for smoking while continuing to allow the importation of the stronger forms popular with millions of patent medicine addicts. A major effect of the law was to produce a substantial increase in the price and decrease in the purity of smoking opium, which led many users to switch to the new and more powerful Heroin pills. This is an example of what economists call the Iron Law of Prohibition - that outlawing a drug results in increased availability and use of the drug in its most potent form (Thornton, 1991 \& 1998; Friedman \& Szasz, 1992; Cowan, 1986).

Following the Shanghai meeting, Bishop Brent informed President Roosevelt that to appear a leader in this effort in the eyes of the world, the US needed to pass a federal law prohibiting the sale and use of opium. The campaign to pass the law was led to a largely by US Opium Commissioner Hamilton Wright, who described opium as "the most pernicious drug known to humanity"(Marshal, 1911) - a view quite different from its usual medical description at the time of opium as "God's own medicine" (Duncan \& Gold, 1982). He also made the assertion, without any evidence but quite possibly true, that "Of all the nations of the world, the United States consumes most [sic] habit-forming drugs per capita" (Marshal, 1911). The campaign to pass an anti-opium bill introduced Americans to many myths that continue to make up America's image of drugs and drug users.
A second opium conference was held two years after the first at The Hague, which drafted the first international drug control treaty, the International Opium Convention of 1912. A series of subsequent meetings developed on the foundation of these agreements has built the framework for today's international cooperation toward the goal of narcotics prohibition.

The first federal opium prohibition bill was submitted by Republican Congressman David Foster of Vermont in 1910. Testimony for the bill emphasized America's obligation to lead in the worldwide campaign against opium. The bill failed to pass, however, through the opposition of Southern Democrats who dominated Congress and who saw the measure as an improper expansion of federal authority into the area of medicine.

By 1914, when the bill was reintroduced, this time by a Democrat, Congressman Francis Harrison, the bill's backers were ready to take a different approach. Wright and his fellow prohibitionists had gained the strong support of the new US Secretary of State, William Jennings Bryan -- also a strong proponent of prohibition of alcohol and most famously a few years later of the teaching of evolution - but they no longer were emphasizing international treaty obligations. Their new strategy to gain the votes of Southern Democrats, who had opposed the previous bill, included adding to the bill's targets the increasingly popular drug heroin and also cocaine, which was seen as popular among African-Americans in the South. More important, they placed their emphasis explicitly on supposed domestic problems replete with racial slurs (Sterling, 2004; Musto, 1973 \&1999). The Southern Democrats found this bill's expansion of federal police power more palatable when it was presented as a response to such purported facts as, "most of the attacks upon white women of the South are the direct result of a cocainecrazed Negro Brain" (Musto, 1999, p. 305).

Dr. Wright testified that "cocaine is often the direct incentive to the crime of rape by the Negroes of the South and other sections of the country," and also stated that "one of the most unfortunate phases of smoking opium in this country is the large number of women who have become involved and were living as common-law wives or cohabitating with Chinese in the Chinatowns of our various cities" (McCarthy, 1910, p 173). This racist appeal produced the swift passage of the Harrison Narcotics Act of 1914.In the words of McNamara (2004), "This racist nonsense would be 
laughed at today, but it was quite influential in the passage of anti-drug legislation."

Another myth promoted during the campaign for prohibition of cocaine was the idea that Black men when high on the drug could not be stopped by shooting them with a .32 caliber handgun - then the most common police firearm. Williams (1914) claimed, regarding Black "coke fiends," that "Bullets fired into vital parts, that would drop a sane man in his tracks, fail to check the 'fiend' -- fail to stop his rush or weaken his attack." According to Thomas (1986) a 1910 federal survey reported that "Southern sheriffs believed cocaine even rendered blacks impervious to .32-cal. bullets (as a result many police departments switched to .38-cal.)."

The Harrison Narcotics Act was followed five years later by the Eighteenth Amendment and the Volstead Act prohibiting the manufacture and sale of alcohol in the US. Alcohol prohibition was different in many ways from the prohibition of other drugs. For one thing, while there were some racist slurs - against Native Americans, Italians, and the Irish among others alcohol and its users were not associated primarily with minorities in the minds of alcohol prohibitionists. For another, possessing or drinking alcohol was never criminalized under alcohol prohibition in the way that possession and use of heroin or cocaine came to be under drug prohibition. Even during the height of alcohol prohibition twice as many persons were imprisoned for drugs as for alcohol offenses (Schmeckebier, 1929). ${ }^{1}$

Prohibition of marijuana seems like prohibition of opium, heroin, and cocaine in having been primarily a racially motivated action aimed at suppressing labor market competition. While poets and preachers in New England may have eaten hashish for spiritual and "transcendental" experiences in the preceding Century, most Americans in the 1930s associated marijuana with Mexicans and Black jazz musicians. While the economy was booming in the 1920s, most Americans were happy to hire Mexican and African-American laborers to do jobs that White Americans did not want.

\footnotetext{
${ }^{1}$ While we are going to leave alcohol prohibition largely out of our narrative, some have suggested that it did play one major part in the growing list of drugs demonized and outlawed. That role is one reason that marijuana was outlawed. According to this theory, repeal of alcohol prohibition left an army of federal Prohibition Agents unemployed and they and their friends in Congress outlawed marijuana to create jobs for them in the Federal Narcotics Bureau. Given that alcohol prohibition was repealed in 1933 and the Marihuana Tax Act wasn't passed until 1937, this does not seem likely.
}

However, with the Great Depression, there were plenty of White workers eager to take those jobs that had seemed too hard or menial in times of prosperity. Demonizing marijuana and its users was a useful tool for putting Mexican-Americans at a disadvantage just as doing so for opium had been useful against the Chinese. White labor leaders, politicians and publishers created the narrative that Mexicans were marijuana users and marijuana use caused violence. As Sterling (2004) says, "The drive to maintain white privilege helped to outlaw marijuana."

Since the end of Reconstruction following the Civil War every Democratic presidential candidate could rely on the votes of the states of the "solid South." Northern Democrats' support for civil rights had been the cause of increasing disaffection among Democrats in the South, as epitomized by the Southern delegates who walked out of the 1948 Democratic National Convention when the Party adopted a platform statement supporting civil rights. Governor Strom Thurmond was subsequently nominated for President as the candidate of the States' Rights Democratic Party, more widely known as the "Dixiecrats." but most returned to the party after Thurmond was soundly defeated by both Truman and Dewey in the 1948 election.

Then, in 1964, Sen. Barry Goldwater, the Republican presidential nominee, voted against the Civil Rights Act of 1964 and campaigned as an advocate for state's rights, which then as in 1948 was understood by most as meaning segregation and White supremacy. Goldwater was the first presidential candidate to raise crime in the streets as a major political issue apparently relying on voters to see it too as code for danger from minorities (Chambliss and Sbarbaro, 1993). Although he was badly beaten by Lyndon Johnson in the 1964 election, Goldwater was the first Republican presidential candidate since Reconstruction to carry states in the Deep South, winning in Alabama, Georgia, Louisiana, Mississippi, and South Carolina.

Alabama Governor George Wallace's successes in the 1964 Democratic primaries in Indiana, Maryland and Wisconsin during his bid for the Presidency showed that racism won votes in the North as well as the South. Richard Nixon hoped to win the South, as well as racists' votes in the North, without offending more traditional Republican voters by an openly racist campaign. The answer Nixon and his advisers found was to campaign against crime, which most Americans 
quite falsely equated with minorities. So what if the crime rate was declining. Americans seem to always believe that crime is increasing or that some "crime wave" is occurring despite actual crime levels (Chevigny, 2003; Roshier, 1973). Likewise, they seem to always blame it on cultural or racial outsiders (Tonry, 2009; Sterling, 2004; Chevigny, 2003; Nunn, 2002).

In 1968, when Richard Nixon was making his comeback run for the presidency, he adopted the socalled "southern strategy" (Brown, 2004; Childs, 1970) that has been crucial to Republican victories in presidential races ever since (Tonry, 2009; Brown, 2004; Kalk, 2001;Aistrup, 1996). This strategy was to make a racist appeal to voters without directly referring to race. To do this they adopted the use of "code words," such as "crime" or "drugs" which voters associated with African-Americans and "states rights" which voters knew meant continued segregation and suppression of voting rights.

Even better than campaigning against crime, the Nixon team soon realized, was campaigning against drugs. Most Americans -- again falsely -- equated drug users with violent criminals. Better still, for that great "silent majority" whose votes they sought, a campaign against drugs symbolized a campaign against both African-Americans and the much hated hippies and anti-war protestors. Thus, Nixon's declaration of a "War on Drugs" in 1971 was an extension and refinement of his southern strategy, which appealed to the basest elements of the American electorate. It was a successful strategy for Nixon, just as it has worked for other candidates since.

The electoral success of his anti-crime/anti-drug campaign presented Nixon with a serious dilemma when he took office -the voters were expecting results. At first his administration tried admitting that constitutionally crime control was a state responsibility and proposed acting through support of training programs and grant-in-aid to state and local police forces. This approach, however, had little political pizzazz and was largely abandoned after it failed to impress the public. Nixon had some ideas of his own, such as a nationwide mandatory death penalty for selling drugs -- a strategy tried in China and in Singapore and appears to have failed in both nations. Fortunately, he was more interested in foreign policy and left the search for a solution to the drug problem in the hands of the White House Domestic Policy Council, chaired by his advisor John Ehrlichman (Gray, 1998; Baum, 1997). One key outcome of this search for a winning policy in what Nixon would soon name the War on Drugs was the Controlled Substances Act (CSA), which was enacted into law by Congress as Title II of the Comprehensive Drug Abuse Prevention and Control Act of 1970. This law made it an administrative decision to prohibit drugs in the future rather than a matter requiring passage of a new law.

The key figure in giving direction to the Domestic Policy Council's search for a drug policy was Egil "Bud" Krogh Jr. -- a young lawyer who is better remembered as the man who headed the White House "plumbers" of Watergate fame. In one of his other roles, as liaison to the government of the District of Columbia, Krogh had become acquainted with psychiatrist Robert Dupont who was running one of the early methadone maintenance programs in Washington, DC. Krogh was reluctant to accept a maintenance approach to addiction but he did see that it was the one approach that had some evidence of effectiveness. In June of 1970, Krogh sent the Council's youngest lawyer Jeffrey Donfeld to visit methadone programs in New York City and Chicago. His visits included the first methadone program, operated by Vincent Dole and Marie Nyswander of New York's Rockefeller University. He also visited a "mixed modality" model developed by University of Chicago psychiatrists Jerome Jaffe and Edward Senay that offered a range of treatments that included detoxification, drug-free, and methadone maintenance.

Donfeld was dubious about the claimed effectiveness of methadone treatment and had even greater doubts about its political acceptability. In terms that have since become familiar, he wondered if methadone maintenance would "send the wrong message" by accepting a continuing addiction to one drug as a treatment for the addiction to another. Donfeld, however, found Jaffe to be "politically sensitive" to these emotional issues raised by methadone maintenance. He believed that the "mixed modality approach," by offering methadone as just one in an array of services would effectively mask the methadone program from political criticism. He called this approach as "different strokes for different folks."

Krogh and Donfeld asked Dr. Jaffe for his recommendation on how to deal with heroin use among U.S. military personnelin Vietnam. Following a visit to the troops in Vietnam, Congressmen John Steele and Morgan Murphy had reported to Congress their estimate that 15 percent of all Gls in Vietnam were addicted to heroin. The existing Defense Department 
policy was one of combining military discipline with "amnesty." Any soldier found using or possessing illicit drugs was subject to court martial and dishonorable discharge from the service. Drug users who voluntarily sought help, however, were to be offered brief treatment and "amnesty" from prosecution. Reports that heroin use was continuing to grow indicated that this policy was failing (Brush, 2002).

Jaffe's advice was for the Pentagon to subject all Gls to urinalysis before shipping them home at the end of their tour of duty. Those who tested positive for heroin would have to stay in Vietnam and undergo detoxification treatment there. The numbers testing positive for heroin were lower than expected and fell over time, which has been interpreted by many (c.f., Massing, 2000) as indicating that Gls were so eager to get home that they quit using heroin to avoid being held longer in Vietnam.

Jaffe himself has indicated that he saw the matter differently (Jaffe and Harris, 1974). As an academic and researcher he was aware of the growing evidence that most heroin users did not become addicted (Duncan, White, \& Nicholson, 2003; Harding, Zinberg, Stelmack, \& Barry, 1980; Zinberg, N. E., Harding, Stelmack, \& Marblestone, 1978; Zinberg, \& Jacobson, 1976; Lewis \& Zinberg, 1964). Furthermore, he knew that early follow-ups showed that, after returning home, most of the troops who were addicted to heroin in Vietnam abstained successfully and usually without any treatment. He did not expect the urine screening program to deter heroin use among the troops while serving in Vietnam. What he expected was that once the urinalysis program was announced heroin using soldiers who were not addicted would stop using for the last weeks before rotation home and only the truly addicted would be unable to do so, thus failing the urine test and being shunted into compulsory detoxification. This is apparently what happened but it gave the politically useful appearance of a far greater success.

Subsequently, a follow-up study of Vietnam veterans conducted by Lee $N$. Robins and her colleagues supported Jaffe's view of the matter (Robins, Helzer, Hesselbrock, \& Wish, 2010; Robins, Helzer, \& Davis, 1975; Robins, Davis, \& Goodwin, 1974). Among their findings was the fact that almost half the Army's enlisted men in Vietnam had used heroin but only about one-fifth of those who used heroin had become addicted. Furthermore, they also found that most of the military personnel who became addicted to heroin while serving in Vietnam recovered fully and permanently after returning to the US, most without ever entering treatment. In the 8- to 12-month period since their return, about $10 \%$ of the returned veterans had used opiates on one or more occasions, but less than $1 \%$ had shown signs of opiate dependence. The researchers were even more surprised to find that some ex-addicts were continuing to use heroin occasionally without falling back into addiction. A reasonable hypothesis might be that military personnel who became addicted to heroin in the stressful environment of the war zone could use it recreationally once they had returned home to a less stressful environment (Duncan, 1974) - a perspective that runs counter to the views of heroin and of addicts that has been a foundation of prohibitionist policy namely that heroin is so powerfully addictive that any use is nearly certain to produce lifelong addiction.

Donfeld and Krogh arranged a meeting between President Nixon and Jaffe at the White House. Nixon floated his idea of a nationwide death penalty for drug dealing, which Jaffe suggested to him would have almost no effect and that if law enforcement had any role in drug policy it was simply that of pushing up prices and thus encouraging addicts to enter treatment. Jaffe attempted to make four points in this meeting, each of which was to bear fruit in shaping the future of drug policy under Nixon. First was the need for more research and evaluation of treatment, which led to the creation of the National Institute on Drug Abuse and the National Institute on Alcoholism and Alcohol Abuse. Second, given the extent of heroin addiction, he urged that methadone maintenance should not be restricted to a few small research projects but should be made widely available, which produced a major swing in federal policy. Third, he urged that funding for treatment be dramatically increased, which Nixon subsequently did. Finally, he told the President that a dozen different federal agencies were funding treatment without any coordination of efforts or coherent national strategy, which led to the creation of the Special Action Office for Drug Abuse Prevention (SAODAP). About a year later, Jaffe was startled to find himself being introduced at a White House press conference as the first director of SAODAP -making him the nation's first "drug czar."

As drug czar, Jaffe convinced the Nixon administration to increase funding for drug abuse treatment eightfold over what it had been when Nixon took office. For the only time so far since America began its failed experiment with drug prohibition, the 
treatment budget was larger (twofold) than that for drug law enforcement. Unfortunately, this bright spot in a century of dysfunctional policy was not to last.

Unfortunately the later Twentieth Century offered further examples of irrational drug policy founded on drug myths that served as almost a mirror image to the cocaine and narcotics fiascoes of the first part of the century. For example, in the 1970s and 1980s reports were widely circulated claiming that phencyclidine (PCP) users were not stoppable with .38 caliber firearms. Many police forces responded by upgrading to .44 caliber weapons. As with the earlier claims for invulnerability to bullets by cocaine users, this was nothing but myth and propaganda. Also, like those earlier stories, these accounts were consistently about African-American men.

Besides being virtually bulletproof, PCP users were also widely reported to have superhuman strength. While in actuality PCP results in muscular weakness not enhanced strength, accounts of people putting their fist through sheetrock and the like while "dusted" were misinterpreted as evidence of super strength rather than of the anesthetizing effects of the drug. In the 1991 case against police officers who had beaten Rodney King it was falsely claimed by the officers that the beating was necessary because he was "dusted" (on PCP) and thus could not be controlled otherwise (Independent Commission on the Los Angeles Police Department, 1991). This meme is still commonly encountered both in TV crime shows and news media.

Another drug scare focused on "crack" cocaine. Previously, cocaine users had used the drug either by injecting it or by sniffing it. Drinking it in beverages such as colas or wine had been popular in the late Nineteenth and early Twentieth Centuries but was largely a thing long past (Duncan \& Gold, 1982). As the cocaine trade from South America grew, many of those involved became familiar with the practice of smoking the crude cocaine base (basuco) that is one stage in refining cocaine. It may have been confusion between the term cocaine base and the free base of cocaine, its basic, non-salt form, that led to the discovery of smoking freebase but this practice soon gained popularity due to its quick onset of effects and ease of titrating one's dose to get just as high as one wished and no more (Duncan, 1987). While cocaine smoking remained associated with White upwardly mobile users it got little media or political attention and, whether they sniffed, injected, or smoked the drug, most cocaine addicts could get treatment and became recovered addicts (Acker, 1993 \& 2010).

When drug dealers in the inner city began offering small packets of a cheap form of cocaine free base known as "crack" or "rock" it suddenly became a public menace in the eyes of the media to a degree it had not been when its users were more mainstream. This new attention included a large collection of the usual sort of myths: "crack" was different from or a purer form of cocaine than the usual powder form; addiction to "crack" was instantaneous after one time use; "crack" addiction was virtually incurable; users of "crack" were prone to violence; and, of course, criminals were using "crack" to entrap women and girls into lives of prostitution.

Most prominent of the "crack" myths was that of "crack babies." Chasnoff, et al. (1985) first raised concerns about cocaine-exposed infants in a short report on a pilot study of 28 pregnant women who had used cocaine. The researchers expressed concern that cocaine use by pregnant women could lead to developmental problems for the infants although they acknowledged that the sample size of their study was too small to demonstrate any such effects. While this research was based on the intranasal use of cocaine by pregnant women, media reports focused on the new phenomenon of "crack."

Subsequent reports in both the mass media and professional journals seemed to take prenatal damage to the cocaine exposed child for granted. A study by Chasnoff, Landress, and Barrett (1990) of the prevalence of drug use during pregnancy in one Florida countyled to a widely quoted estimate of 375,000 "crack babies" being born every year in the US. Citing this estimate, Washington Post columnist Charles Krauthamer (1989, p. C7) wrote that,

A cohort of babies is now being born whose future is closed to them from day one. Theirs will be a life of certain suffering, of probable deviance, of permanent inferiority. At best, a menial life of severe deprivation. And all this is biologically determined from birth.

Boston University President John Silber, decried the expenditure of billions of dollars on the care of "crack babies" who he asserted "won't ever achieve the intellectual development to have consciousness of God" (Saltus, 1991, p. 15). In all the media it seemed that, as described by Acker (2010, p. 83), "images of black 'crack babies' excited alarmed pity while they portended future dependents on tax-payer dollars" 
Even those who recognized that the estimate of 375,000 such infants annually was absurdly high did not seem to question the universality of their handicap. While Besharov (1989a \& 1989b), for instance, argued that there were more likely 30,000 to 50,000 crack babies born annually, he too described them as profoundly damaged and added to this a description of their mothers as universally neglectful and often abusive. A rapidly growing body of literature described crack using mothers as "incapable of responsible decision making, morally deviant, and increasingly, unfit for motherhood. .." while "the image of trembling, helpless infants irrevocably damaged by their mothers' irresponsible actions became a potent symbol of all that was wrong with the poor, the Black, and the new mothers in the post-women's movement, post-civil rights era" (Logan, 1999, p. 115). Child welfare authorities acted to terminate the parental rights of mothers who tested positive for cocaine and prosecutors charged crack using mothers with crimes such as delivering drugs to a minor and even attempted murder (Logan, 1999; Roberts, 1990; Reinarman \& Levine, 2004).

Eventually, follow-up studies of "crack babies" proved the warnings to be untrue (Vargas, 2010; Mercer, 2009; Ornes, 2006). A research review by Ackerman, Riggins, and Black (2010), for example, concluded that "studies through 6 years have shown no long-term direct effects of prenatal cocaine exposure (PCE) on children's physical growth, developmental test scores, or language outcomes." Tronick and Beeghly (1999) reported that, "toddlers and young children who are exposed prenatally to cocaine exhibit few, if any, consistent differences in developmental functioning compared with demographically similar, nonexposed, age-matched controls." This is not to deny that babies prenatally exposed to cocaine (whether crack or powder) are likely to suffer some negative effects, but it is uncertain whether these effects are more due to the drug exposure or to such common factors as poor maternal nutrition. Even the certainty that crack addicted mothers were necessarily bad parents is factually unsupportable (Duncan, 1998).

In the instances discussed above as well as the drug scares responsible for other substances being added to the growing list of illegal drugs, there has been a consistent pattern of outlawing drugs based on scares or "moral panics" (Hawdon, 2001; Reinarman, 1994). The drugs that were the focus of these scares were typically associated with some racial or other group who were perceived as threatening "outsiders" to the dominant White power structure. The drug in question seemed always to be depicted as seductively appealing and contributing directly to moral degradation and violent behavior. The addictive properties, if any, of the drug were always exaggerated both in terms of the likelihood of becoming addicted and the improbability of recovery.

To this point, these authors have tried to provide a brief historical summary and synopsis of drug prohibition both worldwide and in the United States of America. We have paid particular attention to summarizing the Twentieth Century including its policy peculiarities and absurdities. As public health professionals, we have also tried to point out the unintentional and unnecessary harms of these policies. The untold missed opportunities to effectively mitigate the real and serious harms related to drug addiction.

After more than a century of drug prohibition, an estimated 22.5 million Americans aged 12 or older are still current illicit drug users, meaning they used an illicit drug during the past month (Substance Abuse and Mental Health Services Administration [SAMHSA], 2012a). This represents 8.7 percent of the US population aged 12 or older. Included in these numbers are 18.1 million current users of marijuana, 1.4 million of cocaine, and 0.3 million of heroin. SAMHSA also reports that 6.5 million Americans $(2.5 \%$ of the population age 12 or older) are dependent on or abusing illicit drugs. This after one-hundred years of prohibition.

Also paradoxically, SAMHSA reports more heroin addicts/abusers $(426,000)$ than of current heroin users $(281,000)$. The same report indicates that there were 620,000 persons who used heroin during the past year, but how any could be categorized as heroin addicts when they were not currently using seems problematic at best. Such classification of persons as heroin addicts when they were not currently using seems typical of the sort of distortion that we are addressing in this paper. Is this just another example of continuing US government propaganda in the War on Drugs?

Similarly, an argument could be made that drug use and abuse globally has also remained endemic. The United Nations Office on Drugs and Crime (UNODC), for example, "estimates that between 155 and 250 million people, or $3.5 \%$ to $5.7 \%$ of the population aged15-64, had used illicit substances at least once in the previous year." Cannabis users comprise the largest number of illicit drug users (129-190 million 
people) with 16-38 million of these being problem users (UNODC, 2010, 123).

What do such high levels of illegal drug use and abuse after a century of prohibition say about the effectiveness of the policy of prohibition? This criticism does not even address the negative sequelae associated with the War on Drugs, such as a large black market for drugs, political and economic corruption, and burgeoning prison populations (Nadelmann, 1988 \& 1989).

We posit that at some fundamental level society has accepted the idea of the addict as a "monster" to be feared rather than a sick person to be treated. Ironically, in the Nineteenth Century the addict was often viewed as a sinner beholden to demons or the Devil. Hence the expression "demon rum" and the use of prayer and religious retreat to overcome what was perceived as a personal moral failure. This may have helped a few addicts but was severely inadequate to address the growing substance abuse problems of the period. Ironically, in just a few decades we went from classifying the addict as a wretched weakling and sinner to being a dangerous and threatening criminal. An evolution to be sure, but scarcely a positive adaptation.

Whatever the drug involved may be, addiction is a chronic relapsing mental disorder (American Society of Addiction Medicine, 2011; McLellan, Lewis, O'Brien, \& Kleber, 2000). Apparently the sequelae of substance abuse disorders are qualitatively different from other chronic disorders and can more often affect people around the person with the disorder as well as affecting society- sequelae such as driving under the influence, domestic abuse, etc. The question is how society and its healthcare system can best deal with this complex situation. Clearly policies founded on prohibition have failed to cope effectively and humanely with this situation. A century of this failure should be long enough to convince us that we need to try something different.

This policy of prohibition has also had many effects on how treatment of drug abuse is conceptualized and conducted. One instance is the emphasis on addiction as a lifelong disorder. While research supports the view of addiction as chronic, often long-term, and prone to relapse, the idea of "once an addict, always an addict" is purely an opinionated statement contradicted by the evidence from natural history studies. Would we say, "once tubercular, always tubercular" or "once a cancer victim, always cancerous." Clearly, we would not. Yet the demonization of drug users that has been a part of the history of drug prohibition encourages us to accept this claim without question.

Similar to this is society's near hysteria over addict parents. While it is true that many drug abusers make bad parents, it is hardly universally the case that they are abusive or neglectful. More than this, the concept of "addict parent" has very often been applied to parents who are non-addicted, occasional users. Any evidence of marijuana use by a parent may trigger an investigation by child protective services in most parts of America. The same is not true for parental use of alcohol or tobacco - both addictive substances that sicken and kill many more persons than do all illegal drugs combined (Mokdad, Marks, Stroup, and Gerberding, 2004). What of parents who smoke in their homes, thus exposing their children to secondhand smoke? How is this not a concern but a parent's occasional smoking of marijuana outside their child's environment is abusive?

Probably the clearest effect on treatment of the policy of prohibition is the commitment to an abstinence only model of therapy. Once the drug and its user have been caricatured as evil it seems unthinkable to accept any treatment outcome short of complete and total abstinence. Such binary thinking is not used with most other chronic disorders. This attitude has delayed the acceptance of methadone treatment, Suboxone ${ }^{\circledR}$ therapy, and other forms of harm reduction. All human beings eventually suffer from disease. Some are cured, others are managed, and still others are tolerated. Why must substance abuse alone be handled in such an absolutist way?

Everyone who works with substance abusers is aware that the numbers needing treatment greatly exceed the number of treatment slots available. This is particularly so for low income individuals with substance abuse problems. Even for those who can afford private care or who have adequate insurance coverage, waiting lists for admission are commonplace. While there are multiple reasons for the shortage of care, a major reason is that most of the budget for substance abuse is committed to law enforcement and other supply reduction efforts.

One result of this shortage of treatment slots is that many who are in need of therapy instead wind up in prison. Prison in place of treatment seems particularly cruel and absurd. 
Given the demand for an abstinence only approach to treatment under a policy of prohibition, research on alternative approaches goes largely unsupported. There has been very little funding available from either public or foundation sources for research on any type of therapy aimed at moderating rather than terminating illegal drug use. Heroin maintenance, for instance, has been studied only in Europe (European Monitoring Centre for Drugs and Drug Addiction, 2012). Harm reduction strategies, such as syringe exchange and safe injection rooms, were not the subject of government research until unfunded research had proven they could no longer be ignored (Small, Palepu, \& Tyndall, 2006; Broadhead, et al., 2002; Satcher, 2000).

The treatment of substance abuse disorders needs to be seen as a purely public health and medical problem. We argue that along with the abject failure of a century of prohibition to achieve its stated goal of eliminating use and abuse of certain drugs, prohibition has had a powerful negative impact on the treatment of substance abuse disorders.

What might be some changes in our substance abuse treatment system if we abandoned our national commitment to prohibition and the goal of a drug-free society? For one thing, it would mean that patients would no longer be treated as criminals subject to imprisonment for non-compliance or relapse. Treatment professionals would no longer be performing double duty as de facto probation officers enforcing abstinence regardless of their patients' wants or needs.

A major difference would be that healthy functioning, with or without drug use, would be the goal of treatment rather than a "one size fits all" commitment to abstinence as the only acceptable goal (Nicholson, Duncan, \& White, 2002). Treatment would be better able to meet the addict where she or he is. Requirements for addicts to make a commitment from the outset to a drug-free life style or to stop the use of all psychoactive drugs before entering care would become things of the past.

Maintenance treatments, in which a person addicted to a drug is given safe regular doses of that drug or a substitute drug rather than being withdrawn from the drug of abuse, would become more widely accepted. Addiction would increasingly come to be seen as just another chronic condition that some people are struggling with.
Mainstreaming the treatment of all substance abuse disorders would allow for their integration into primary, secondary and tertiary prevention programs. Heretofore, difficult if possible, when supply reduction remains the dominant policy focus. The authorization of office based treatment with Suboxone $\circledR$ is an example of the possibilities of mainstreaming. As is the extensive practice of providing methadone maintenance through primary care physicians in the Netherlands (Duncan \& Nicholson, 1997). A large part of the medical treatment and aftercare for addicts could be provided through primary caregivers if it were not for the supply reduction restrictions engendered by a prohibition policy.

Elimination of the enormous costs of drug law enforcement and the prison industrial complex would free up resources some of which hopefully would be used to support more treatment. Too much emphasis on police, borders, and prisons takes away from efforts by educators and treatment specialists.

We are treating our chronically ill fellow citizens and family members cruelly and inhumanely. A hundred years is long enough. Time for change is clearly upon us. It is time to start erasing the perception of the addict as monster and accept them as the fallible human beings that we all are.

\section{REFERENCES}

Acker, C. J. 2010. "How Crack Found a Niche in the American Ghetto: The Historical Epidemiology of Drug-related Harm." BioSocieties 5: 70-88. http://dx.doi.org/10.1057/biosoc.2009.1

Acker, C. J. 1993. "Stigma or Legitimation? A Historical Examination of the Social Potentials of Addiction Disease Models." Journal of Psychoactive Drugs 25: 193-205. http://dx.doi.org/10.1080/02791072.1993.10472271

Ackerman, J. P, Riggins, T, \& Black, M. M. 2010. "A Review of the Effects of Prenatal Cocaine Exposure Among School-aged Children." Pediatrics 125(3): $554-565$. http://dx.doi.org/10.1542/peds.2009-0637

Aistrup, J. A. 1996. The Southern Strategy Revisited: Republican Top-down Advancement in the South. Lexington, KY: University Press of Kentucky.

Alexander, M. 2011. The New Jim Crow: Mass Incarceration in the Age of Colorblindness. New York: The New Press.

American Society of Addiction Medicine. 2011. Public Policy Statement: Definition of Addiction. Adopted by the ASAM Board of Directors April 19, 2011. Chevy Chase, MD: author. Accessed June 4, 2014 at http://www.asam.org/researchtreatment/definition-of-addiction

Baum, Don. 1996. Smoke and Mirrors: The War on Drugs and the Politics of Failure. New York: Little, Brown \& Co.

Baumohl, J. 2000. "Maintaining Orthodoxy: The Depression-era Struggle Over Morphine Maintenance in California." Contemporary Drug Problems 27(1): 17-75.

Bertram, E., Blachman, M., Sharpe, K., \& Andreas, P. 1996. Drug War Politics: The Price of Denial. Berkeley, CA: University of California Press. 
Besharov, Douglas. 1989a. "Crack Babies: The Worst Threat is Mom Herself." The Washington Post. August 6, B, 1. Accessed June 4, 2014 at http://www.welfareacademy.org/pubs/ childwelfare/crackbabies_89_0806.pdf

Besharov, Douglas. J. (1989b). "The children of crack." Public Welfare 47(4): 6-11. Accessed June 4, 2014 at: http://www.welfareacademy.org/pubs/childwelfare/childrenofc rack_89.pdf

Bewley-Taylor, D.R. 1999. The United States and International Drug Control. London: Pinter Publishers Ltd.

Boyd, S., Fang, L. J., Medoff, D., Dixon, L., and Gorelick, D. 2012. "Use of a 'Microecologic Technique' to Study Crime Incidents Around Methadone Maintenance Treatment Centres." Addiction 107: 1632-1638. http://dx.doi.org/10.1111/j.1360-0443.2012.03872.x

Brecher, Edward. M., and the Editors of Consumer Reports Magazine. 1972. The Consumers Union Report on Licit and Illicit Drugs. New York: Little, Brown \& Co.

Broadhead, R. S., Kerr, T. H., Grund, J. P. C., \& Altice, F. L. 2002. Safer Injection Facilities in North America: Their Place in Public Policy and Health Initiatives." Journal of Drug Issues 32(1): 329-355. http://dx.doi.org/10.1177/002204260203200113

Brooks, Jerome E. 1952. The mighty Leaf: Tobacco Through the Centuries. New York: Little, Brown \& Co.

Brown, F. 2004. 'Nixon's 'Southern Strategy' and Forces Against Brown." Journal of Negro Education 191-208. http://dx.doi.org/10.2307/4129605

Brush, P. 2002. "Higher and Higher: American Drug Use in Vietnam." Vietnam Magazine 5(4): 46-53, 70. Accessed June 4, 2014 at http://www.library.vanderbilt.edu/central/Brush/Americandrug-use-vietnam.htm

Campbell, N. D., Olsen, J. P., and Walden, L. 2008. The Narcotic Farm: The Rise and Fall of America's First Prison for Drug Addicts. New York: Abrams Books.

Chambliss, W. J. 1995. "Crime control and Ethnic Minorities: Legitimizing Racial Oppression by Creating Moral Panics." Pp. 235-258 in Ethnicity, race, and crime: Perspectives across time and place, edited by D. F. Hawkins. Albany: SUNY Press.

Chambliss, W. J., \& Sbarbaro, E. 1993."Moral panics and racial oppression." Socio-Legal Bulletin 8: 4-13.

Chasnoff, I. J. 1993. "Missing Pieces of the Puzzle." Neurotoxicology and Teratology 15: 287-288. http://dx.doi.org/10.1016/0892-0362(93)90022-G

Chasnoff, I. J. 1989. "Drug Use and Women: Establishing a Standard of Care." Annals of the New York Academy of Science 562: 208-210. http://dx.doi.org/10.1111/j.1749-6632.1989.tb21019.x

Chasnoff, I., Burns, W., Schnoll, S. H., and Burns, K. A. 1985. "Cocaine use in pregnancy." New England Journal of Medicine 313: 666-669. http://dx.doi.org/10.1056/NEJM198509123131105

Chasnoff, I. J., Landress, H. J., \& Barrett, M. E. 1990. "The Prevalence of Illicit-drug or Alcohol use During Pregnancy and Discrepancies in Mandatory Reporting in Pinellas County, Florida." New England Journal of Medicine322(17): 1202-1206. http://dx.doi.org/10.1056/NEJM199004263221706

Chevigny, P. 2003. "The Populism of Fear Politics of Crime in the Americas." Punishment \& Society 5(1): 77-96. http://dx.doi.org/10.1177/1462474503005001293

Childs, M. 1970. "Wallace's Victory Weakens Nixon's Southern Strategy." The Morning Record, June 8. Accessed June 4, 2014 at: http://news.google.com/newspapers?id=hy9IAAAAl BAJ\&sjid=egANAAAAIBAJ\&pg=1221,5431957\&dq=southern -strategy\&hl=en
Corti, Egon Caesar. 1932. History of Smoking. New York: Harcourt, Brace \& Co.

Courtwright, David T. 1982. Dark Paradise: Opiate Addiction in America Before 1940. Cambridge, MA: Harvard University Press.

Cowan, Richard C. 1986. "How the Narcs Created Crack." National Review, December 5, pp. 30-31. Accessed June 4, 2014 at http://www.drugtext.org/pdf/Cocaine-crack-and-base/howthe-narcs-created-crack.pdf

Davis, B. L. 1982. "The PCP Epidemic: A Critical Review." Substance Use \& Misuse 17(7): 1137-1155. http://dx.doi.org/10.3109/10826088209056346

Densten, J. C. (1917). "Drug Addiction and the Harrison Anti-narcotic Act." New York Medical Journal 105: 747-748.

Dole, Vincent P. (1971). "Methadone Maintenance Treatment for 25,000 Addicts." JAMA: The Journal of the American Medical Association215: 1131-1134. http://dx.doi.org/10.1001/jama.1971.03180200055012

Dole, Vincent P., and Nyswander, Marie. (1965a). Aedical Treatment for Diacetylmorphine (Heroin) Addiction." JAMA: The Journal of the American Medical Association 193: 80-84. http://dx.doi.org/10.1001/jama.1965.03090080008002

Dole, Vincent P., and Nyswander, Marie. (1965b). "A Medical Treatment for Diacetylmorphine (Heroin) Addiction. A Clinical Trial with Methadone Hydrochloride." JAMA: The Journal of the American Medical Association193: 646-650. http://dx.doi.org/10.1001/jama.1965.03090080008002

Dole, Vincent P., and Nyswander, Marie E., and Kreek, Mary J. 1966. "Narcotic blockade." Archives of Internal Medicine 118: 304309. http://dx.doi.org/10.1001/archinte.1966.00290160004002

Dole, Vincent P., and Nyswander, Marie E., and Warner A. 1968. "Successful Treatment of 750 Criminal Addicts." JAMA: The Journal of the American Medical Association 206: 27082711. http://dx.doi.org/10.1001/jama.1968.03150120042009

Drug Policy Alliance N.d. Drug Treatment Access and Options. ACCESSED June 4, 2014 at http://www.drugpolicy.org/ issues/drug-treatment

Duncan, David F. 1974. "The Acquisition, Maintenance and Treatment of Polydrug Dependence: A Public Health Model." Journal of Psychedelic Drugs 7(2): 209-213. http://dx.doi.org/10.1080/02791072.1975.10472000

Duncan, David F. 1977. "Life crisis as a precursor to adolescent drug dependence." International Journal of the Addictions 12(8): 1047-1056.

Duncan, David F. 1987. "Cocaine Smoking and Its Implications for Health and Health Education." Health Education 18(4): 2427.

Duncan, David F., \& Nicholson, Thomas. 1997. "Dutch Drug Policy: A Model for America?" Journal of Health and Social Policy 8(3): 1-15. Accessed June 6, 2014 at: http://www.druglibrary.org/ schaffer/other/dutch.htm

Duncan, David F. 1998. "Prevention Issues: Some Cautionary Notes." Pp. 249-262 in Substance Abuse, Family Violence, and Child Welfare: Bridging Perspectives, edited by R. L. Hampton, V. Senatore, and T. P. Gullotta. Thousand Oaks, CA: Sage.

Duncan, David F., \& Gold, Robert S. 1982.Drugs and the Whole Person. New York: John Wiley and Sons.

Duncan, David F., White, John B., \& Nicholson, Thomas. 2003. "Using Internet-based Surveys to Reach Hidden Populations: Case of Nonabusive Illicit Drug Users." American Journal of Health Behavior 27(3): 208-218. http://dx.doi.org/10.5993/AJHB.27.3.2

Elliott, K. T., and Coker, D. R. (1991). "Crack Babies: Here They Come, Ready or Not." Journal of Instructional Psychology 18(1): 60-64. 
European Monitoring Centre for Drugs and Drug Addiction. 2012. "New Heroin-assisted Treatment: Recent Evidence and Current Practices of Supervised Injectable Heroin Treatment in Europe and Beyond." EMCDDA INSIGHTS No. 11. Luxembourg: Publications Office of the European Union. ACCESSED June 4, 2014 at: http://www.emcdda.europa.eu/ attachements.cfm/att_154996_EN_Heroin\%20Insi...

Fellner, Jamie. 2000. Punishment and Prejudice: Racial Disparities in the War on Drugs. New York, NY: Human Rights Watch.

Ferentzy, Peter. (2011). Dealing With Addiction: Why the Twentieth Century Was Wrong. Raleigh, NC: Lulu.com

Fields, Gary. 2009. "White House Czar Calls for End to 'War on Drugs'." The Wall Street Journal, May 14Accessed June 4, 2014 at http://online.wsj.com/article/SB124225891527617 397.html

Frampton, Mary L., Lopez, Ian H., \& Simon, Jonathan. (2008). After the War on Crime: Race, Democracy, and a New Reconstruction. New York: NYU Press.

Friedman, Milton, and Szasz, Thomas. 1992. On Liberty and Drugs, Essay on the Free Market and Prohibition. Washington, D.C.: The Drug Policy Foundation Press.

Frost, L. (2005). Never One Nation: Freaks, Savages, and Whiteness in U.S. Popular Culture, 1850-1877. Minneapolis: University of Minnesota Press.

Galliher, John F., \& Walker, Allynn. 1978. "The Politics of Systematic Research Error: The Case of the Federal Bureau of Narcotics as a Moral Entrepreneur." Crime and Social Justice10: 29-33.

Giroux, Henry A. (2003). "Racial Injustice and Disposable Youth in the Age of Zero Tolerance." International Journal of Qualitative Studies in Education 16(4): 553-565 http://dx.doi.org/10.1080/0951839032000099543

Gray, Mike. 1998. Drug Crazy: How We Got into This Mess and How We Can Get Out. New York: Random House.

Hamid, Ansley. (1992). "The Developmental Cycle of a Drug Epidemic: The Cocaine Smoking Epidemic of 1981-1991." Journal of Psychoactive Drugs 24(4): 337-348. http://dx.doi.org/10.1080/02791072.1992.10471658

Harding, Wayne M., Zinberg, Norman E., Stelmack, Shirley M., \& Barry, Michael. 1980. "Formerly-addicted-now-controlled Opiate Users." Substance Use \& Misuse 15(1): 47-60. http://dx.doi.org/10.3109/10826087109045543

Hartman, Donna M., \& Golub, Andrew. 1999. "The Social Construction of the Crack Epidemic in the Print Media." Journal of Psychoactive Drugs 31(4): 423-433. http://dx.doi.org/10.1080/02791072.1999.10471772

Hawdon, James E. 2001. "The Role of Presidential Rhetoric in the Creation of a Moral Panic: Reagan, Bush, and the War on Drugs." Deviant Behavior 22(5): 419-445. Accessed June 4, 2014 http://dx.doi.org/10.1080/01639620152472813

Helmer, John. 1975. Drugs and minority oppression. New York: Seabury Press.

Helmer, John, \& Vietorisz, Thomas. 1974. Drug use, the labor market and class conflict. (Vol. 43, No. 8). Washington, DC: Drug Abuse Council.

Hoffmann, John P. 1990. "The Historical Shift in the Perception of Opiates: From Medicine to Social Menace. Journal of Psychoactive Drugs 22(1): 53-62. Accessed June 8, 2014 at: http://www.tandfonline.com/doi/abs/10.1080/02791072.1990. 10472197

Hoffman, Robert S. 2000. Is methadone a miracle cure or an Alternative evil? Western Journal of Medicine 172(1): 15-16. http://dx.doi.org/10.1136/ewjm.172.1.15

Holcomb, Jefferson E., Williams, Marian R., and Demuth, Stephen. 2004. "White female victims and death penalty disparity research." Justice Quarterly 21(4): 877-902. http://dx.doi.org/10.1080/07418820400096021
Hulse, G. K, English., D. R., Milne, E., Holman, C. D. J. and Bower, C. I. 1997. "Maternal cocaine use and low birth weight newborns: a meta-analysis." Addiction 92(11): 1561-1570. http://dx.doi.org/10.1111/j.1360-0443.1997.tb02876.x

Independent Commission on the Los Angeles Police Department. 1991. Report of the Independent Commission on the Los Angeles Police Department. Los Angeles: Accessed Oct. 2, 2012 at http://www.parc.info/client_files/Special Reports/1 Chistopher Commision.pdf

Jaffe, Jerome H., and Harris, G. T. (1973)."As Far As Heroin Is Concerned, The Worst Is Over." Psychology Today 85: 68$79,85$.

Jaffe, Jerome H., and O'Keeffe, Charles. 2003. "From morphine clinics to buprenorphine: regulating opioid agonist treatment of addiction in the United States." Drug and Alcohol Dependence, 70(2 Suppl): S3-S11. http://dx.doi.org/10.1016/S0376-8716(03)00055-3

Jasinski, Donald R., Pevnick, Jeffrey S., and Griffith, John D. 1978. "Human pharmacology and abuse potential of the analgesic buprenorphine: a potential agent for treating narcotic addiction." Archives of General Psychiatry 35(4): 501-516. http://dx.doi.org/10.1001/archpsyc.1978.01770280111012

Joseph, Herman, Stancliff, Sharon, and Langrod, John. 2000. Methadone Maintenance Treatment (MMT): A Review of Historical and Clinical Issues. Mt. Sinai Journal of Medicine 67(5-6): 347-364

Kalk, Bruce $\mathrm{H}$. The Origins of the Southern Strategy: Two-party Competition in South Carolina, 1950-1972. Lexington, MA: Lexington Books.

King, Rufus J. 1953. The Narcotics Bureau and the Harrison Act: Jailing the Healers and the Sick. Yale Law Journal 62: 784787. http://dx.doi.org/10.2307/793503

King, Van L.; Kidorf, Michael S.; Stoller, Kenneth B.; Schwartz, Robert; Kolodner, Kenneth; Brooner, Robert K. 2006. "A 12month Controlled Trial of Methadone Medical Maintenance Integrated Into an Adaptive Treatment Model. Journal of Substance Abuse Treatment 31(4): 385-393. http://dx.doi.org/10.1016/j.jsat.2006.05.014

Kolb, Lawrence, and Du Mez, Andrew G. (1924). "The Prevalence and Trend of Drug Addiction in the United States and Factors Influencing It. Public Health Reports 39(21):1179-1204. http://dx.doi.org/10.2307/4577168

Krantz, Mori J., and Mehler, Philip S. 2004. "Treating Opioid Dependence. Growing Implications for Primary Care." Archives of Internal Medicine 164(3): 277-288. http://dx.doi.org/10.1001/archinte.164.3.277

Krauthammer, Charles. 1989. "Children of Cocaine." July 30, The Washington Post, p. C7.

Lewis, David C., and Zinberg, Norman E. 1964."Narcotic Usage: Historical Perspective on a Difficult Medical Problem." New England Journal of Medicine 270: 1045-1050. http://dx.doi.org/10.1056/NEJM196405142702006

Ling, W, Charuvastra, Charles, Collins, Joseph F., Batki, Steve, Brown, Lawrence S. Jr., Kintaudi, Prudencia, Wesson, Donald R., and Segal, Doralee. 1998. "Buprenorphine Maintenance Treatment of Opiate Dependence: AMulticenter, Randomized Clinical Trial." Addiction 93(4): 475-486. http://dx.doi.org/10.1046/j.1360-0443.1998.9344753.x

Logan, Enid. 1999. "The Wrong Race, Committing Crime, Doing Drugs, and Maladjusted for Motherhood: The Nation's Fury Over 'Crack Babies'." Social Justice 26(1): 115-138. Accessed June 6, 2014 at http://www.jstor.org/stable/ 29767115

Lowes, Peter D. (1966). The genesis of international narcotics control. Geneva: Droz. 
Marshall, E.1911."Uncle Sam is the Worst Drug Fiend in the World." March 12, The New York Times, Magazine Section, p. SM12.

Massing, Michael. (2000). The Fix. Berkeley: University of California Press.

McCarthy, J. J. 1910. "How the Drug Habit Grips the Unwary." July, Pearson's Magazine 24(1): 169-176.

McLellan, A. Thomas, Lewis, David C., O'Brien, Charles P., and Kleber, Herbert D. 2000.“Drug Dependence, A Chronic Medical IIIness: Implications for Treatment, Insurance, and Outcomes Evaluation. JAMA: The Journal of the American Medical Association 284(13): 1689-1695. http://dx.doi.org/10.1001/jama.284.13.1689

McNamara, Joseph D. 2004. "The American Junkie." April 30, Hoover Digest, 2Accessed June 6, 2014 at http://www.hoover.org/publications/hoover-digest/article/6763

Méndez, Juan E. 2010. Report submitted by the Special Rapporteur on torture and other cruel, inhuman or degrading treatment or punishment. UN report to Human Rights Council. A/HRC/22/53 New York: United Nations. Accessed June 6, 2014 at http://www.ohchr.org/Documents/HRBodies/ HRCouncil/RegularSession/Session22/A.HRC.22.53_English .pdf

Mercer, Jean. 2009. "Claim 9: 'Crack Babies' Can't Be Cured and Will Always Have Serious Problems." Pp. 62-64 in Child Development: Myths and Misunderstandings, edited by J. Mercer. Thousand Oaks, CA: Sage.

Merrill, Joseph O. 2002. "Policy Progress for Physician Treatment of Opiate Addiction." Journal of General Internal Medicine17(5): 361-368. http://dx.doi.org/10.1007/s11606-002-0041-6

Miller, Richard L. (1996). Drug Warriors \& Their Prey: From Police Power to Police State. Westport, CT: Praeger.

Mokdad, Ali H., Marks, James S., Stroup, Donna F., and Gerberding, Judie L. 2004. Actual Causes of Death in the United States, 2000.JAMA: Journal of the American Medical Association 291(10): 1242 http://dx.doi.org/10.1001/jama.291.10.1238

Moore, Lisa D., \& Elkavich, Amy. 2008. "Who's Using and Who's Doing Time: Incarceration, the War on Drugs, and Public Health." American Journal of Public Health 98(Supplement 1): S176. http://dx.doi.org/10.2105/AJPH.98.Supplement 1.S176

Morgan, John P., \& Kagan, Doreen.1980. "The Dusting of America: The Image of Phencyclidine (PCP) in the Popular Media." Journal of Psychoactive Drugs 12(3-4): 195-204. http://dx.doi.org/10.1080/02791072.1980.10471426

Morgan, Patricia A. 1978. "The Legislation of Drug Law: Economic Crisis and Social Control." Journal of Drug Issues 8: 53-62.

Musto, David F. (1999). The American Disease, Origins of Narcotic Control (3rd Ed.). New York: Oxford University Press.

Musto, David F., and Ramos, Manuel R. 1981. "Notes on American Medical History: A Follow-up Study of the New Haven Morphine Maintenance Clinic of 1920. New England Journal of Medicine 304(18): 1071-1077. http://dx.doi.org/10.1056/NEJM198104303041804

Nadelmann, Ethan A. 1989. "Drug Prohibition in the United States: Costs, Consequences, and Alternatives. Science 245(4921): 939 http://dx.doi.org/10.1126/science.2772647

Nadelmann, Ethan A. 1988. "US Drug Policy: A Bad Export." Foreign Policy (70): 83-108. http://dx.doi.org/10.2307/1148617

Nicholson, Thomas, Duncan, David F., and White John. (2002). "Is Recreational Drug Use Normal?" Journal of Substance Use 7: 116-123. Accessed June 10, 2014 at: http://informahealthcare.com/doi/abs/10.1080/14659890209169340

Novick, David M., and Joseph, Herman. 1991. "Medical Maintenance: The Treatment of Chronic Opiate Dependence in General Medical Practice." Journal of Substance Abuse Treatment 8(4): 233-239.

http://dx.doi.org/10.1016/0740-5472(91)90044-B

Nunn, Kenneth B. 2002. "Race, Crime and the Pool of Surplus Criminality: Or Why the War on Drugs Was a War on Blacks." Journal of Gender Race \& Justice 6: 381

O'Connor, Patrick G.; Oliveto, Alison H.; Shi, Julia M.; Triffleman, Eliza G.; Carroll, Kathleen M.; Kosten, Thomas R.; Rounsaville, Bruce J.; Pakes, Juliana A.; and Schottenfeld, Richard S. 1998. "A Randomized Trial of Buprenorphine Maintenance for Heroin Dependence in a Primary Care Clinic for Substance Users Versus a Methadone Clinic." American Journal of Medicine 105(2): 100-105. http://dx.doi.org/10.1016/S0002-9343(98)00194-6

Office of Applied Studies. 2009. Results from the 2008 National Survey on Drug Use and Health: National findings (HHS Publication No. SMA 09-4434, NSDUH Series H-36). Rockville, MD: Substance Abuse and Mental Health Services Administration.

Ornes, Stephen. 2006). "What Ever Happened to Crack Babies?" December, Discover Magazine. Accessed at http://discovermagazine.com/2006/dec/crack-baby-unfounded-stigma\#. UVNfoTeRdVg

Reinarman, Craig. (1994). "The social construction of drug scares." Constructions of Deviance: Social Power, Context, and Interaction 92-105.

Reinarman, Craig, and Levine, Harry G. (1989a). "Crack in Context: Politics and Media in the Making of a Drug Scare." Contemporary Drug Problems 16: 535-577.

Reinarman, Craig, and Levine, Harry G. (1989b) "The Crack Attack: Politics and Media in America's Latest Drug Scare." Pp. 115137 in Images of Issues: Typifying Contemporary Social Problems, edited by J. Best. New York: Aldine de Gruyter.

Rettig, Richard A. and Yarmolinsky, Adam. 1995. Federal Regulation of Methadone Treatment. Washington, D.C: National Academy Press.

Roberts, Dorothy E. 1990. "Punishing Drug Addicts Who Have Babies: Women of Color, Equality, and the Right of Privacy." Harvard Law Review 104: 1419-1482. http://dx.doi.org/10.2307/1341597

Robins, Lee N, Davis, Darlene H., and Goodwin, Donald W. 1974 "Drug Use by U.S. Army Enlisted Men in Vietnam: A Followup on Their Return Home." American Journal of Epidemiology 99(4): 235-249

Robins, Lee N., Helzer, John E., and Davis, Darlene H. (1975). Narcotic use in Southeast Asia and afterward: An interview study of 898 Vietnam returnees. Archives of General Psychiatry 32(8): 955-961. http://dx.doi.org/10.1001/archpsyc.1975.01760260019001

Robins, Lee N., Helzer, John E., Hesselbrock, Michie, and Wish, Eric.2010. "Vietnam Veterans Three Years After Vietnam: How Our Study Changed Our View of Heroin." The American Journal on Addictions 19(3): 203-211. http://dx.doi.org/10.1111/j.1521-0391.2010.00046.x

Rosenbaum, Marsha. 1995. "The Demedicalization of Methadone Maintenance." Journal of Psychoactive Drugs 27(2): 145149. http://dx.doi.org/10.1080/02791072.1995.10471683

Roshier, B. (1973). "The Selection of Crime News in the Press." Pp. 28-39 in The Manufacture of News, edited by S. Cohen and J. Young. Beverly Hills: Sage.

Salsitz, Edwin A.; Joseph, Herman; Frank, Blanche; Perez, John; Richman, Beverly L.; Salomon, Nadim; Kalin, Marcia F.; and Novick, David M. 2000. Methadone Medical Maintenance (MMM): Treating Chronic Opioid Dependence in Private Medical Practice -- A Summary Report (1983-1998). Mt. Sinai Journal of Medicine 67(5-6): 388-397. 
Saltus, Richard. 1991. Silber Attacks Health System: Issues Call to Shift Patient Priorities. The Boston Globe, April 30, Metro/Region p. 15.

Satcher, David. (2000). Evidence-Based Findings on the Efficacy of Syringe Exchange Programs: An Analysis of the Scientific Research Completed Since April 1998.Washington, DC: Dept. of Health and Human Services. Accessed June 10, 2014 at http://harmreduction.org/wp-content/uploads/2012/ 01/EvidenceBasedFindingsOnEfficacyofSEPs.pdf

Schmeckebier, L. F. (1929). The Bureau of Prohibition. Service Monograph No. 57. Washington, DC: Brookings Institute. Cited in Rufus King (1957), "Narcotic Drug Laws and Enforcement Policies." Law and Contemporary Problems 22(122): 113-131.

Schottenfeld, Richard S.; Pakes, Juliana R.; Oliveto, Alison; Ziedonis, Douglas; and Kosten, Thomas R. (1997). "Buprenorphine vs Methadone Maintenance Treatment for Concurrent Opioid Dependence and Cocaine Abuse." Archives of General Psychiatry 54: 713-720. http://dx.doi.org/10.1001/archpsyc.1997.01830200041006

Schwartz, Robert P.; Brooner, Robert K.; Montoya, Ivan D.; Currens, Marian; and Hayes, Michael. 1999. "A 12-year Follow-up of a Methadone Medical Maintenance Program." American Journal of Addiction 8: 293-299. http://dx.doi.org/10.1080/105504999305695

Small, Don, Palepu, Anita, and Tyndall, Mark W. 2006. "The Establishment of North America's first State Sanctioned Supervised Injection Facility: A Case Study in Culture Change. International Journal of Drug Policy 17(2): 73-82. ACCESSED June 10, 2014 at http://www.communityinsite. ca/pdf/culture-change-case-study.pdf

Sterling, Eric E. 2004. "Drug Policy: A Challenge of Values." Journal of Religion and Spirituality in Social Work 23(1/2): 51-81. http://dx.doi.org/10.1300/J377v23n01 04

Substance Abuse and Mental Health Services Administration (2012a). Results from the 2011 National Survey on Drug Use and Health: Summary of National Findings, NSDUH Series H-44, HHS Publication No. (SMA) 12-4713. Rockville, MD: Substance Abuse and Mental Health Services Administration. Accessed June 10, 2014 at http://www.samhsa.gov/ data/NSDUH/2k11Results/NSDUHresults2011.htm

Substance Abuse and Mental Health Services Administration (2012b). Results from the 2011 National Survey on Drug Use and Health: Mental Health Findings. NSDUH Series H-45, HHS Publication No. (SMA) 12-4725. Rockville, MD: Substance Abuse and Mental Health Services Administration. Accessed June 10, 2014 at http://www.samhsa. gov/data/NSDUH/2k11MH_FindingsandDetTables/2K11MHF R/NSDUHmhfr2011.pdf

Substance Abuse and Mental Health Services Administration (2001). "Opioid Drugs in Maintenance and Detoxification Treatment of Opiate Addiction; Final Rule." Federal Register 66: 40754102.

Thomas, E. 1986. America's Crusade: What Is Behind the Latest War on Drugs. September 15,Time Magazine pp. 60-66, 86. Accessed June 10, 2014 at http://content.time.com/time/ magazine/article/0,9171,962287,00.html
Thornton, Mark. 1991. The Economics of Prohibition, Salt Lake City, UT: University of Utah Press, 1991.

Thornton, Mark. 1998. "The Potency of Illegal Drugs." Journal of Drug Issues 28(3): 725-740.

Timmer, Ashley S., and Williamson, Jeffrey G. (1996). "Racism, Xenophobia or Markets? The Political Economy of Immigration Policy Prior to the Thirties." NBER Working Paper no. 5867. Cambridge, MA: National Bureau of Economic Research.

Tonry, Michael. 2009. "Explanations of American punishment policies A national history." Punishment \& Society 11(3): 377-394. http://dx.doi.org/10.1177/1462474509334609

Tronick, Edward Z., \& Beeghly, Margaret. 1999. "Prenatal Cocaine Exposure, Child Development, and the Compromising Effects of Cumulative Risk." Clinics in Perinatology 26(1): 151-171.

United Nations Office on Drugs and Crime 2009.A Century of International Drug Control. Vienna, Austria: United Nations.

United Nations Office on Drugs and Crime 2010.World Drug Report 2010. Vienna, Austria: United Nations.

Vargas Theresa. 2010. "Once Written Off, 'Crack Babies' Have Grown Into Success Stories. The Washington Post, April 18. Accessed June 10, 2014 at: http://www.washingtonpost. com/wp-dyn/content/article/2010/04/15/AR2010041502434. html

Waldorf, Dan, Orlick, Martin, and Reinarman, Craig. (1974). Morphine maintenance: The Shreveport Clinic, 1919-1923. Washington, DC: Drug Abuse Council

Walley, Alexander Y.; Alperen, Julie K.; Cheng, Debbie M.; Botticelli, Michael; Castro-Donlan, Carolyn; Samet, Jeffrey H.; and Alford, Daniel P. (2008). "Office-Based Management of Opioid Dependence with Buprenorphine: Clinical Practices and Barriers." Journal of General Internal Medicine 23(9): 1393-1398. http://dx.doi.org/10.1007/s11606-008-0686-x

White, William L. (1998). Slaying the Dragon: The History of Addiction Treatment and Recovery in America. Bloomington, IL: Chestnut Health Systems/Lighthouse Institute.

Williams, Edward H. 1914. "Negro Cocaine 'Fiends' New Southern Menace." The New York Times, Sunday, February 8.Accessed June 10, 2014 at: http://druglibrary.net/schaffer/ History/negro_cocaine_fiends.htm

Wolfe, Daniel, and Saucier, Roxanne.2010. "In Rehabilitation's Name? Ending Institutionalized Cruelty and Degrading Treatment of People Who Use Drugs." International Journal of Drug Policy 21(3): 145-148. http://dx.doi.org/10.1016/j.drugpo.2010.01.008

Wood, Evan; Werb, Daniel; Marshall, Brandon D. L.; Montaner, Julio S. G.; and Kerr, Thomas. 2009."The War on Drugs: A Devastating Public-policy Disaster." Lancet 373:989-990. http://dx.doi.org/10.1016/S0140-6736(09)60455-4

Zentner, Joseph L. 1976. "The Recreational Use of LSD-25 and Drug Prohibition." Journal of Psychoactive Drugs 8(4): 299-305. Accessed June 10, 2014 at: http://www.tandfonline.com/doi/ abs/10.1080/02791072.1976.10471853

Received on 12-06-2014

Accepted on 03-07-2014

Published on 23-07-2014

DOI: http://dx.doi.org/10.6000/1929-4409.2014.03.17

(C) 2014 Duncan et al.; Licensee Lifescience Global.

This is an open access article licensed under the terms of the Creative Commons Attribution Non-Commercial License (http://creativecommons.org/licenses/by-nc/3.0/) which permits unrestricted, non-commercial use, distribution and reproduction in any medium, provided the work is properly cited. 